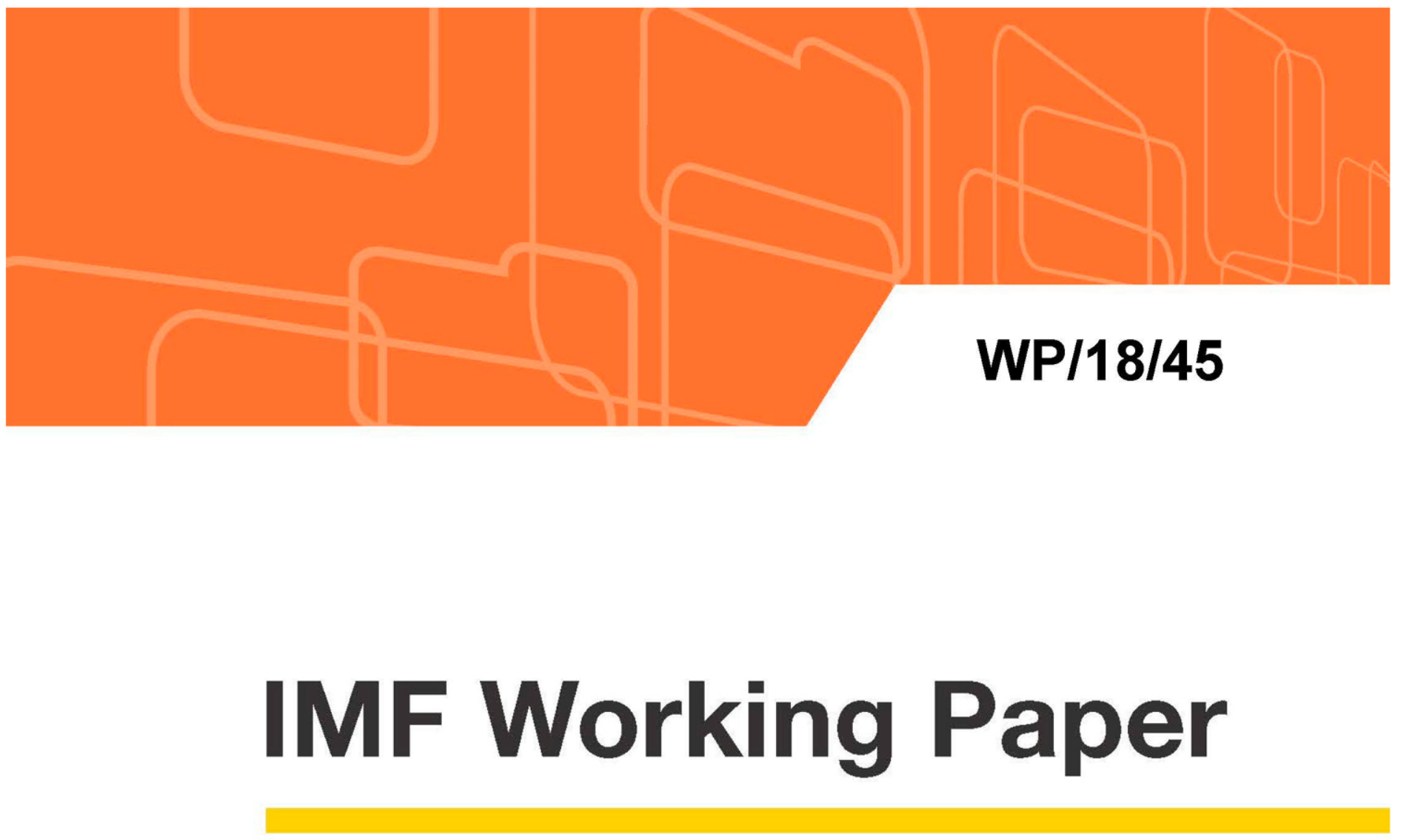

\title{
Banks' Maturity Transformation: Risk, Reward, and Policy
}

by Pierluigi Bologna

IMF Working Papers describe research in progress by the author(s) and are published to elicit comments and to encourage debate. The views expressed in IMF Working Papers are those of the author(s) and do not necessarily represent the views of the IMF, its Executive Board, or IMF management. 


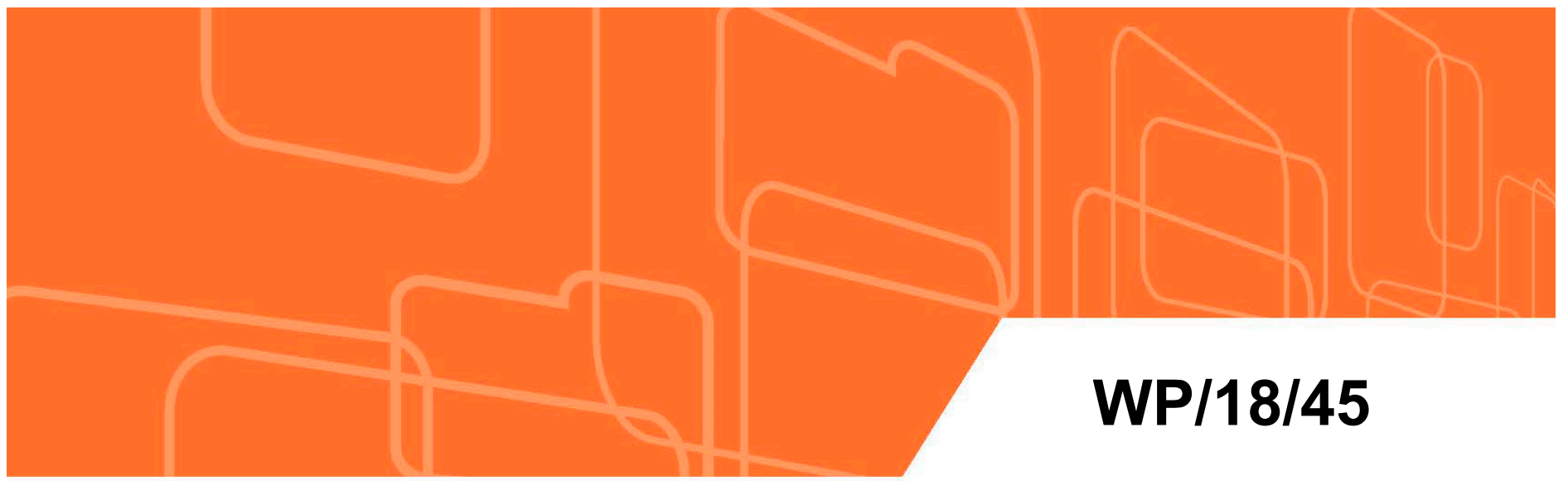

IMF Working Paper

\section{Banks' Maturity Transformation: Risk, Reward, and Policy}

by Pierluigi Bologna

IMF Working Papers describe research in progress by the author(s) and are published to elicit comments and to encourage debate. The views expressed in IMF Working Papers are those of the author(s) and do not necessarily represent the views of the IMF, its Executive Board, or IMF management.

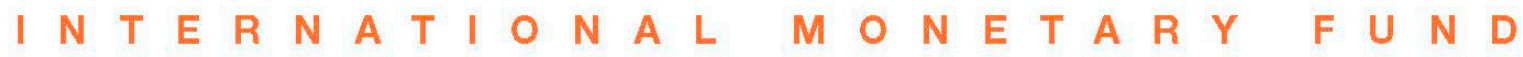




\title{
IMF Working Paper
}

Monetary and Capital Markets Department

\section{Banks’ Maturity Transformation: Risk, Reward, and Policy \\ Prepared by Pierluigi Bologna*}

Authorized for distribution by Nigel Jenkinson

February 2018

\begin{abstract}
The aim of this paper is twofold: first, to study the determinants of banks' net interest margin with a particular focus on the role of maturity transformation, using a new measure of maturity mismatch; second, to analyse the implications for banks from the relaxation of a binding prudential limit on maturity mismatch, in place in Italy until mid-2000s. The results show that maturity transformation is a relevant driver of the net interest margin, as higher maturity transformation is typically associated with higher net interest margin. However, 'excessive' maturity transformation - even without leading to systemic vulnerabilitiesincreases banks' interest rate risk exposure and lowers their net interest margin.
\end{abstract}

JEL Classification Numbers: E43, G21, G28

Keywords: banks, profitability, maturity transformation, interest rates, macroprudential, microprudential

Author's E-Mail Address: pierluigi.bologna@bancaditalia.it

\footnotetext{
* Banca d'Italia, Financial Stability Directorate. I dedicate this paper to Andrea Generale. I am grateful to the Monetary and Capital Markets Department of the International Monetary Fund for hosting me during the preparation of this work. I would like to thank Piergiorgio Alessandri, Lucy Gornicka, Marc Dobler, Pierpaolo Grippa, Gee Hee Hong, Nigel Jenkinson, Mitsuru Katagiri, Erlend Nier, Steve Phillips, and Alberto Franco Pozzolo for their comments. I would like to thank also Fabio Coluzzi for providing support with the data and Rebecca Shyam for excellent editorial assistance. Last, but not least, I am indebted to Marco Bevilacqua who provided essential support and with whom I had very stimulating exchanges of views during the various stages of the work. The views expressed are my own and should be attributed neither to the Banca d'Italia nor to the International Monetary Fund. All errors are my sole responsibility.
} 


\section{Contents}

I. Introduction

II. The Main Literature on the Determinants of Banks' Net Interest Margin and the Role of Maturity Transformation....

III. Model

A. Net Interest Margin and Maturity Transformation

B. Net Interest Margin, Balance Sheet, and Risk with a Regulation on Maturity

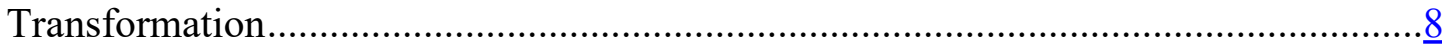

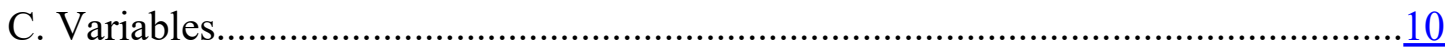

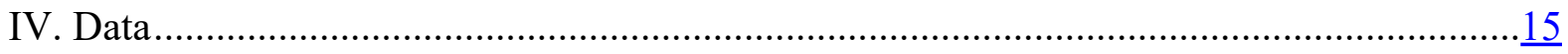

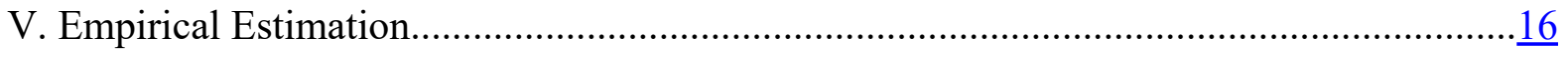

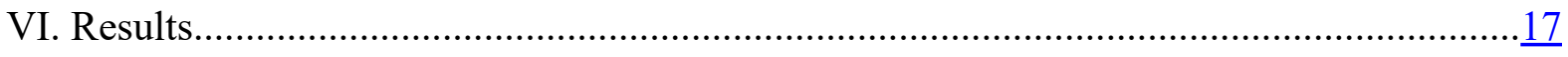

A. Net Interest Margin, Maturity Transformation, and Interest Rates.......................17

B. Net Interest Margin, Balance Sheet, and Risk with a Regulation on Maturity

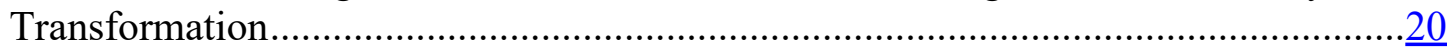

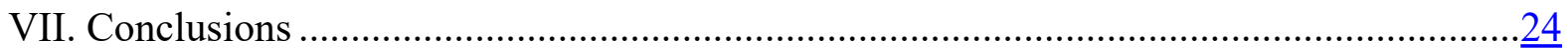

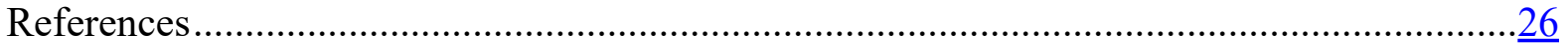

\section{Tables}

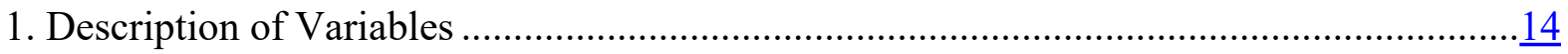

2. Sample Composition: Number of Banks and Asset Size ....................................... 15

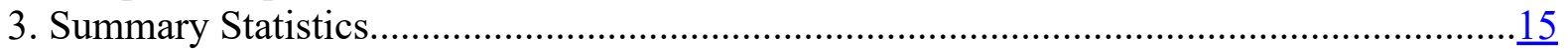

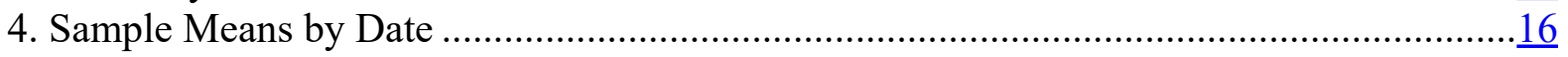

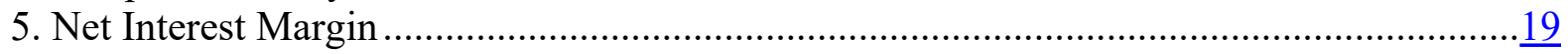

6. Policy Change and Assets and Liabilities Composition .............................................

7. Policy Change and Asset and Liability Composition by Interest Rate .............................22

8. Policy Change and Bank Risk Exposure ...........................................................

9. Policy Change and Net Interest Margin.....................................................................24

\section{Figures}

1. Average Maturity Transformation by Bank Type ................................................. 10

\section{Appendix}

I. The Italian Regulatory Limit on Bank Maturity Transformation. 


\section{Glossary}

BCBS Basel Committee on Banking Supervision

ECB European Central Bank

GFC Global Financial Crisis

GMM Generalized Methods of Moments

LCR Liquidity Coverage Ratio

NPL Nonperforming Loan

NSFR Net Stable Funding Ratio 


\section{INTRODUCTION}

Maturity transformation is a key function of banking. ${ }^{1}$ Banks are still called to transfer funds from agents in surplus demanding short-term deposits to agents in deficit with long-term financing needs (Hicks, 1946) despite the notable evolution of banks' activity through the years. The maturity mismatch needed to facilitate long-term investment projects while serving investors' liquidity needs should allow banks to earn a spread in an environment where the yield curve is positively sloped. One could argue that, while such financial intermediation exposes banks to credit and interest rate risk, banks charge a fee for carrying such risks, and the more banks ride the yield curve the higher should be their profitability most of the time, i.e. during 'normal' (non-crisis) periods. At the same time, banks might have incentives to excessively increase maturity mismatch (Brunnermeier and Oehmke, 2013 among others) exposing themselves to high funding risk related to the need to roll-over shortterm liabilities. During a funding crisis, banks may find that the cost of their short-term liabilities soars, with a negative effect on profitability. Therefore, excessive maturity transformation exposes banks to tail risks that have the potential to threaten not only their stability, even if highly-rated (van Rixtel and Gasperini, 2013), but also that of the whole financial system. Consequently, excessive maturity transformation is undesirable from a financial stability perspective (Hellwig, 2008). The Global Financial Crisis (GFC) has been a case in point of the non-linearities that can emerge from excessive maturity transformation, with structural funding weaknesses being a key driver of banks' failures (among others, Vasquez and Federico, 2012, International Monetary Fund, 2013, and Bologna, 2015).

Despite the relevance of maturity transformation for banking, the empirical literature on the relationship with bank profitability is still very scant. At the same time, while the need for oversight and restrictions on maturity mismatch has been acknowledged as a way to reduce rollover risk and preserve financial stability (Goldstein and Turner, 2004), also with the introduction of the Net Stable Funding Ratio (NSFR) by the Basel Committee on Banking Supervision (BCBS) (2010 and 2011), there is essentially no empirical literature on the evaluation of policies related to banks' maturity mismatch.

Our interest is therefore to shed light on the relationship between bank profitability, maturity transformation, and the role of policies targeting banks' maturity mismatch. We focus in particular on the net interest income, a key component of bank profitability, and show that in normal times higher maturity transformation increases banks' net interest margin, particularly in the context of a steeper yield curve, with higher short-term interest rates also having a positive effect. An increase in interest rates and/or a steepening of the yield curve might have however undesirable effects in the short-term due to non-negligible re-pricing frictions. We also find that an 'excessive' maturity transformation-proxied by a maturity

\footnotetext{
${ }^{1}$ In the context of this paper, the terms maturity transformation and maturity mismatch are considered as synonymous and used interchangeably, and refer to the difference in the residual contractual maturity between assets and liabilities.
} 
transformation higher than a limit that was in place in Italy until mid-2000s (Banca d'Italia, 2006) - could imply a higher risk exposure without improving bank net-interest margin.

These findings are relevant in light of: (i) the forthcoming introduction of the NSFR, a prudential limit on banks' structural funding risk, in many respects similar to the aforementioned Italian supervisory regulation; (ii) the possible use of policy tools on maturity mismatches in a time-varying fashion for macroprudential purposes, as suggested by the European Central Bank (ECB) (2014), the European Systemic Risk Board (2014a and 2014b), and the International Monetary Fund (2014); and (iii) the expected phasing-out of expansionary monetary policy and the following increase in interest rates.

This paper innovates the literature in two ways. First, it uses a novel measure of maturity transformation which takes fully into account the actual contractual maturity of both assets and liabilities. Second, it is the first study to analyze how banks responded to a regulatory loosening of a limit on maturity mismatch. The still unripe literature on the effects of changes in regulations has in fact mainly dealt with regulatory tightenings and, in the context of liquidity regulations, with tools more similar to short-term liquidity measures à la Liquidity Coverage Ratio (LCR) (Banerjee and Mio, 2014; Bonner, 2012; Bonner and Eijffinger, 2012; de Haan and van den End, 2013; and Duijm and Wierts, 2016).

The rest of the paper is structured as follows. Section II presents a short review of the main contributions to the literature about the determinants of banks' net interest margin and the role of maturity transformation. Section III describes the empirical strategy. Section IV presents the dataset, Section V the estimation framework, and Section VI the results. Section VII concludes.

\section{The Main Literature on the Determinants of BANKS' Net Interest Margin AND THE ROLE OF MATURITY TRANSFORMATION}

The empirical literature on the determinants of the net interest margin builds on the dealership model of Ho and Saunders (1981) and its subsequent extensions. A bank in this model is a risk-averse intermediary between lenders and borrowers. It charges a fee for providing a liquidity service, i.e., for immediately accepting deposits and granting loans without waiting for a matching transaction. Whenever the volume of loans does not match the volume of deposits, the bank resorts to the short-term money market to close the gap (i.e., to finance loans exceeding the amount of deposits or to invest deposits in excess) thereby bearing a refinancing or reinvestment risk. Such a risk is covered by charging a fee which increases with interest rate volatility. Importantly, in the original model by Ho and Saunders (1981) loans and deposits have the same one-period maturity, therefore there is no other source of interest rate risk or maturity mismatch. Additional explanatory factors underpinning interest spreads are the bank's risk aversion, the average transaction size and the degree of competition in the reference market. 
Extensions to this seminal setup have followed from the relaxation of some of the simplifying assumptions. Among the key advancements, Angbazo (1997) extends the model to incorporate credit risk (and its interaction with interest rate risk). The model-implied prediction on the positive sign of credit risk is however confirmed in the empirical analysis on U.S. banks only for 'money center' banks and not for regional banks; in addition, Angbazo (1997) is the first to use a bank-specific measure of interest rate risk (proxied by the net position of short-term, 12 months or less, assets) finding a positive relation with the net interest margin, although only for regional banks. Maudos and Fernández de Guevara (2004) have further extended the framework to take operating costs explicitly into account. The estimation, over a sample of European banks, confirms that higher interest rate risk (measured by the standard deviation of interest rates), credit risk, and operating costs are reflected in higher net interest margin. The stream of empirical research stemming from these contributions has been focusing on both model-derived hypotheses and the use of additional control variables. Most studies use proxies for credit risk, interest rate risk, and operating costs as the key explanatory variables underpinning net interest margin; market structure, institutional factors and macroeconomic drivers are also controlled for in many of the available research.

Only recently Entrop et al. (2015) proposed a further extension of the baseline model by Ho and Saunders (1981) to explicitly account for the interest rate risk resulting from bank maturity mismatch. To this end, they relax the crucial hypothesis of identical loan and deposit maturity. Therefore, interest rate risk exposure does not only depend on bank duration gap, but also on bank maturity structure. Confirming the testable hypothesis implied by their model, the authors find that for German banks the net interest margin increases in the banks' duration gap but this positive effect is partially offset by a higher maturity transformation, proxied by a term spread of the duration implied par yield of assets and liabilities. The intuition is that while banks with higher interest rate risk exposure stemming from holding long-term assets charge higher (lower) loan (deposit) fees to cover this risk, banks partly offset this effect by taking account of positive 'holding period returns,' i.e., they transfer to customers part of the benefits they expect from 'riding' the yield curve to secure term spreads, although the economic significance of this effect is rather limited. In other words, although interest rate risk and maturity transformation are related concepts, according to Entrop et al. (2015), they separately contribute to net interest margin. A higher maturity mismatch creates more room to take on interest rate risk which needs to be compensated by higher fees; at the same time, the higher term spread earned can be partially passed on to customers, partly offsetting these higher fees.

\section{MODEL}

\section{A. Net Interest Margin and Maturity Transformation}

To study the determinants of banks' net interest margin and the role of maturity mismatch we use a model of the following linear form: 
$\Pi_{i t}=c+\sum_{j=1}^{J} \beta_{j} X_{i t}^{j}+\sum_{m=1}^{M} \beta_{m} X_{t}^{m}+\varepsilon_{i t} \quad \varepsilon_{i t}=v_{i}+u_{i t}$

where $\Pi_{i t}$ is the net interest margin of bank $i$ at time $t$, with $i=1, \ldots, \mathrm{N}$ and $t=1, \ldots, \mathrm{T}$ semester. $c$ is a constant term, $X_{i t}$ are bank-specific explanatory variables, and $X_{t}^{m}$ are controls to account for time varying common factors, such as industry-specific controls and either macroeconomic controls or time dummies. $\varepsilon_{i t}$ is the error term, with $v_{i}$ being the bank-specific component and $u_{i t}$ the idiosyncratic factor.

Since bank profits typically exhibit a persistence over time, due to the time needed to balance sheet adjustments and/or possible obstacles to competition and/or the sensitivity to macroeconomic shocks to the extent that they are serially correlated (Berger et al., 2000), we also estimate and dynamic version of equation (1) which include a lagged term of the dependent variable.

$$
\Pi_{i t}=c+\alpha \Pi_{i t-1}+\sum_{j=1}^{J} \beta_{j} X_{i t}^{j}+\sum_{m=1}^{M} \beta_{m} X_{t}^{m}+\varepsilon_{i t} \quad \varepsilon_{i t}=v_{i}+u_{i t}
$$

A value between 0 and 1 of the coefficient of the lagged term indicate a persistence of the net interest margin.

\section{B. Net Interest Margin, Balance Sheet, and Risk with a Regulation on Maturity Transformation}

To study the implications for banks following a change in a regulation on maturity mismatch, we look at the Italian experience with a prudential limit on maturity transformation, which has been in place from 1993 to 2005 and then removed as of June 2006. ${ }^{2}$ This regulatory change can be considered an exogenous policy decision which allowed banks to increase their maturity mismatch beyond the pre-existing limit. ${ }^{3}$ Not all banks responded in the same way: some increased their maturity transformation beyond the limit while others did not. Since the regulation was equally applied to all banks, the increase in maturity transformation after the policy change can be considered to depend only on the banks' management choice about the asset and liability allocation across the maturity spectrum. We can study therefore the implications in terms of risk exposure, balance sheet composition, and net interest margin of this policy change, by looking at the banks that increased their maturity mismatch beyond the pre-existing limit relatively to those that did not.

To analyze the net interest margin, balance sheet, and risk exposure following the regulatory

\footnotetext{
${ }^{2}$ The main characteristics of the Italian regulation are described in Appendix I.

${ }^{3}$ The exogeneity of the policy measure is motivated also by the fact that at the time of the regulatory change the Bank of Italy did not carry out formal consultations with the industry before amending prudential regulations. Hence there was no formal ex ante communication of a possible forthcoming change in regulation.
} 
change we use a model of the following form:

$Y_{i t}=c+\beta_{1} h i g h_{i t}+\beta_{2} p o l_{t}+\beta_{3} h i g h_{i t} \times p o l_{t}+\beta_{4} X_{i t}+\sum_{m=5}^{M} \beta_{m} X_{t}^{m}+\varepsilon_{i t}$

where $Y$ is the variable of bank $i$ at time $t$, with $i=1, \ldots, \mathrm{N}$ and $t=1, \ldots, \mathrm{T}$, for which we analyze the change following the change in the regulation. As $Y$ we use ten alternative bank-specific variables, described in the following paragraph. $c$ is a constant term, high is a dummy variable equal to 1 for the 'high maturity transformation' banks, i.e., the banks that increased their maturity transformation above the pre-existing limit, and 0 for the others, $p o l$ is a dummy variable equal to 0 when the limit on maturity transformation is in place (i.e., until 2005Q4) and 1 after it is revoked (as of 2006Q2). The interaction of high and pol is therefore equal to 1 for the banks that increased their maturity mismatch above the pre-existing limit in the post-policy change period, and 0 otherwise. $X_{i t}$ is the bank asset size, $X_{t}^{m}$ are macroeconomic controls, and $\varepsilon_{i t}$ is the error term.

We identify the banks that increased their maturity transformation beyond the pre-existing limit (from now on also defined 'constrained' banks for brevity), in the two alternative ways:

a. banks that have exceeded the pre-existing regulatory limit of 100 at least once after the regulatory change, and that during the five years before the change had an average maturity transformation lower than $90 .{ }^{4}$

b. Banks that had an average maturity transformation higher than 100 after the regulatory change, and that during the five years before the change had an average maturity transformation lower than 90 .

The definition sub $b$ is stricter than that sub $a$ but both provide a clear separation between the banks that have increased their maturity transformation above the limit after the policy change and those that have not (either because they remained at relatively lower levels or were already at a high level, a possibility that cannot be ruled out, for transitory periods and in case of supervisory tolerance). As shown in Figure 1, the average maturity transformation of the constrained and unconstrained banks grows in parallel in the five years before the policy change but then after the change the maturity transformation of the constrained banks grows much faster than that of the other banks.

\footnotetext{
${ }^{4}$ The prudential limit was not expressed in these terms (see Appendix I for further details) but it can be simply rearranged so to express the limit as equal at 100 . Hence any value below 100 is within the limit.
} 


\section{Figure 1. Average Maturity Transformation by Bank Type}

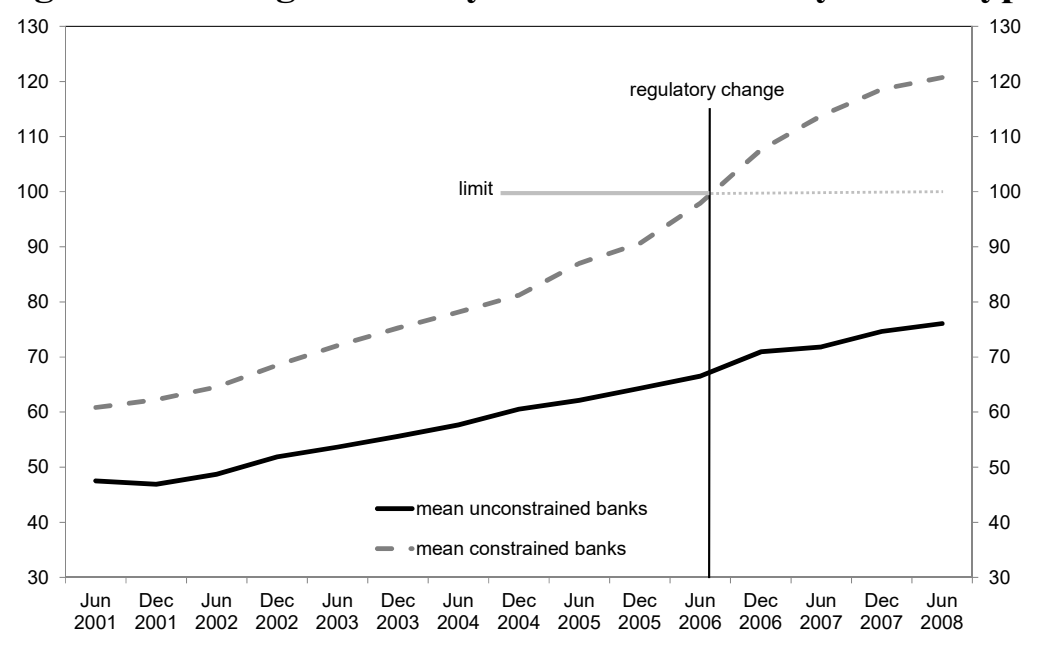

Constrained and unconstrained banks are identified according to the criteria defined in Section III.B sub

\section{Variables}

\section{Credit risk}

Most of the available empirical research on the determinants of interest margins shows that credit risk-often proxied by nonperforming loans (NPLs) to total assets or by loan loss provisions to total assets-exert a positive effect (Angbazo 1997, Maudos and Fernández de Guevara 2004; Maudos and Solís 2009, among the others). This means that banks charge additional risk premiums to compensate for higher credit risk. Williams (2007) finds however a negative association between credit risk (measured by loan loss provisions) and net interest margin, explaining the result with the buying market share effect (DeYoung and Nolle, 1996), which would also be reflected in bank portfolio quality. ${ }^{5}$ We note that proxying credit risk with NPLs or, depending on how they are computed, even with loan loss provisions, should indeed result in a negative relationship with the net interest margin. NPLs are in fact a materialization of credit risk and, even if they were properly priced when granted, they do not accrue interest once they become nonperforming and should therefore negatively weight on banks' margin. Hence, in line with Entrop et al. (2015), as a measure of forward looking credit risk exposure we use the ratio of risk-weighted assets to total assets. This should guide banks' decisions about the level of the appropriate risk premium to be charged to compensate for the credit risk exposure. Thus, it can be expected to be positively related with the net interest margin. ${ }^{6}$

\footnotetext{
${ }^{5}$ Buying market share would tend to result in lower quality loans being granted. Higher levels of loan loss provisions would subsequently result, and would not be fully compensated for by net interest margins, reflecting mispricing.

${ }^{6}$ While the average risk weight could reflect also the riskiness of assets other the loans, it should be considered an appropriate proxy for the Italian banking system which is largely credit-based and has risks other than credit playing only a marginal role.
} 


\section{Interest rate risk}

Interest rate risk is usually found to be positively related to banks' net interest margin (Angbazo 1997; Entrop et al. 2015; Hawtrey and Liang 2008; Maudos and Fernández de Guevara 2004; and Saunders and Schumacher 2000, among others). We measure the bank interest rate risk using the duration gap approach, as in Esposito et al. (2015). The duration gap is computed with the simplified methodology defined by the Banca d'Italia (2006) consistently with the principles stated by the BCBS $(2004,2006) .^{7}$

\section{Maturity transformation}

While Entrop et al. (2015) use a price-based measure of maturity transformation, expressing it in terms of the duration of assets and liabilities, we use a quantity-based measure. We compute maturity transformation as a function of the contractual remaining maturity at time $t$ for each asset, liability and capital instrument. In particular, we take the ratio of banks' weighted assets to weighted liabilities and capital, where assets, liabilities and capital instruments are weighted according to their residual time-to-maturity. ${ }^{8}$ The instruments with the longer maturity are assigned the higher weights. The weights are from the prudential regulation on maturity transformation adopted by the Banca d'Italia (2003). ${ }^{9}$ A notable feature of this measure of maturity transformation, not previously used in the literature, is that it captures the contractual maturity mismatch, i.e., the misalignment between the expiration dates of assets and liabilities. This concept of maturity transformation is not necessarily related to that of re-pricing maturity, as for any given financial instrument in the balance sheet the re-pricing maturity can be shorter than the contractual maturity. By accounting for the misalignment of the contractual maturity of assets and liabilities, this measure of maturity transformation can be interpreted as capturing also the banks' structural refinancing risk. From this perspective, it is therefore a more accurate proxy of banks' structural funding risk than the simpler ratios often used in the literature (e.g., loans-todeposits, loans-to-liabilities, loans-to-assets). Overall a positive relationship between banks' maturity transformation and net interest margin should exist, as banks with a higher maturity

\footnotetext{
${ }^{7}$ According to the regulatory framework banks' interest rate risk is measured by the potential effect on the banks' economic value of a "standardized" interest rate shock, defined as a parallel shift of the entire term structure of interest rates by 200 basis points. The methodology requires that all assets, liabilities and offbalance-sheet items be allocated in 14 maturity buckets according to their remaining time to maturity or, in the case of variable rate items, according to their re-pricing schedule.

${ }^{8}$ Multiplied by 100 .

${ }^{9}$ The weights are assigned based on the residual contractual maturity of assets and liabilities (i.e., the maturity to termination of the contract). On the asset side, investments in real estates and in associates and all assets with maturity longer than 5 years are weighted by 1 ; assets with maturities between 1.5 and 5 years are weighted by 0.5 , all other assets are weighted by 0 . On the liability side, regulatory capital, non-maturing liabilities and liabilities with maturity longer than 5 years are weighted by 1 ; liabilities with maturities between 1.5 and 5 years are weighted by 0.5 ; customer liabilities, including deposits, with maturity up to 1.5 year, and interbank funding with maturities between 3 months and 1.5 year, are weighted by 0.25 (Banca d'Italia, 2003).
} 
transformation should gain higher fees on their assets (or pay lower fees on the liabilities).

\section{Risk aversion}

Risk aversion is often proxied by capital adequacy ratios or by equity to asset ratios. Angbazo (1997), Brock and Rojas (2000), Maudos and Fernández de Guevara (2004), Maudos and Solís (2009), and Saunders and Schumacher (2000), among others, find that higher capital ratios have a positive impact on banks' net interest margin, indicating that banks ask for higher margins to compensate for the cost of holding higher capital. Entrop et. al (2015) proxies risk aversion with excess capital, measured as the ratio of capital in excess to the required minimum to total assets, and also finds a positive relationship with the net interest margin. As Entrop et al. (2015), we also proxy bank risk aversion by excess capital but we measure it as the ratio of capital in excess to the required minimum to total risk-weighted assets. By normalizing excess capital to risk-weighted assets we should control for the level of risk aversion relative to the banks' actual risk exposure, a more appropriate measure than the ratio of excess capital to total assets used by Entrop et al (2015), which may yield a downward biased measure of risk aversion, as total assets-being risk insensitive-are an inflated proxy of the actual bank risk exposure. Our expectation, in line with the literature, is that the net interest margin be positively related to risk aversion.

\section{Operational costs}

In line with most of the literature (Maudos and Fernández de Guevara, 2004; Maudos and Solís, 2009, and Williams, 2007, among the others) we measure bank operational costs as a share to total assets. Based on the findings of the existing literature, we expect that higher operational costs be associated with higher net interest margins as banks that have high unit costs will need to have higher margins to cover such costs.

\section{Size}

The literature presents contrasting results on the relationship between bank net interest margin and size (often proxied by the natural logarithm of either loans or total assets). Albertazzi and Gambacorta (2009), Ho and Saunders (1981), and Maudos and Solís (2009) find a positive relationship. However, despite the ex-ante expectation, Fungáčová and Poghosyan (2011) and Maudos and Fernández de Guevara (2004) report a negative association between bank size and interest margin, also showing that the sign of the relationship changes depending on the bank ownership type (with foreign-owned banks having a positive sign). In line with most of the literature we measure size with the logarithm of total assets and expect a positive relationship with the net interest margin. 


\section{Market structure and concentration}

In an oligopolistic banking system the level of concentration is likely to positively affect the net interest margin by altering the size of oligopoly profits, so that a decline in the number of banks should lead to higher net interest margin. The empirical evidence provides however mixed results. Several studies find that net interest margin tends to increase with bank concentration and market power (Maudos and Fernández de Guevara, 2004; Maudos and Solís 2009; Saunders and Schumacher 2000; and Williams 2007, among others) while Demirgüç-Kunt et al. (2004) show that the positive association between concentration and bank margins disappears when controlling for institutional developments. Claessens and Laeven (2004), who also do not find links between market structure and banks' spreads, attribute this absence to the fact that concentration variables typically used are not good proxies for the degree of competition in the banking sector. Beck and Hesse (2009) reject the positive association between concentration and bank margins, suggesting that contestability and other non-price factors are better measures of bank competition. In line with, among others, Albertazzi and Gambacorta (2009) and Maudos and Fernández de Guevara (2004), we use the Herfindal-Hirschman index to account for the concentration in the banking system and expect that higher concentration leads to higher net interest margin.

\section{Macroeconomic controls}

There is no generally accepted model for including macroeconomic variables to control for the effect of macroeconomic conditions on the evolution of bank interest margins. Ho and Saunders (1980) and its extensions use the volatility of interest rates. Claeys and Vander Vennet (2008), Demirgüç-Kunt et al. (2004), and Laeven and Majnoni (2005), among others, control for inflation and find that it has a positive effect on interest margins through higher loan interest rates. Alessandri and Nelson (2015) for U.K. banks, and English et al. (2012) for U.S. banks use both the level of interest rates and the slope of the yield curve as they are expected to be both positively related to the net interest margin. ${ }^{10}$ Alessandri and Nelson (2015) also argue that there is a need to control separately for the long run and short run effects of interest rates, through level and change terms respectively. While in the long run higher interest rates and steeper yield curves can be expected to have a positive effect on the net interest margin, a negative relationship could be found in the short-term as an interest rate increase/decrease can have a short-term negative/positive effect on the net interest margin, due to non-negligible re-pricing frictions. In our baseline specification, we use a vector of time dummy variables, as in Esposito et al. (2015) and Purnanandam (2007), to control for time-varying group-invariant macroeconomic conditions. Time dummies are useful also to limit potential endogeneity concerns among variables that may be driven by common

${ }^{10}$ Using only the level of interest rates would introduce a bias to the coefficient of the variable which would be constrained to capture both a level and a slope effect. 
macroeconomic factors. Then, in an alternative specification, we replace the time dummies with explicit macroeconomic controls, with a particular focus on the role of interest rates, as in Alessandri and Nelson (2015).

The variables used are reported in Table 1 together with their description and the expected sign. For some of the variables described we study the banks' response to the policy change, as discussed in Section III.B. They are, namely: net interest margin, interest rate risk, credit risk, and risk aversion. In addition, we also study the effect of the policy change on the balance sheet assets and liabilities composition by maturity (long- vs. medium-to-short-term, i.e., maturity longer vs shorter than five years), asset type (mortgage lending), and interest rate (fixed rate vs. floating rate). All these variables area considered as a share of total assets.

Table 1. Description of Variables

\begin{tabular}{|c|c|c|}
\hline Notation & Description & Expected coeff \\
\hline \multicolumn{3}{|l|}{ Bank-specific variables } \\
\hline Net interest margin & Ratio of net interest income to total assets. & \\
\hline Maturity transformation & $\begin{array}{l}\text { Ratio of maturity-weighted assets to maturity-weighted liabilities and } \\
\text { capital. Assets, liabilities and capital are allocated to maturity } \\
\text { buckets depending on their residual time-to-maturity and then } \\
\text { weighted, as described in Banca d'Italia (2003). The weighting } \\
\text { system is such that the longer the maturity the higher the } \\
\text { weightings. }\end{array}$ & + \\
\hline Interest rate risk & $\begin{array}{l}\text { Measured with the duration gap approach described in Banca d'Italia } \\
\text { (2006). All assets, liabilities and off-balance-sheet items are } \\
\text { allocated in maturity buckets according to their remaining time to } \\
\text { maturity or to their re-pricing schedule. For each bucket, assets are } \\
\text { offset against liabilities to produce a net position. The net position of } \\
\text { every time band is then multiplied by a weighting factor based on a } \\
\text { proxy of the modified duration for each time band and on a } \\
\text { hypothetical } 200 \text { basis points parallel shift of the yield curve. A } \\
\text { positive (negative) duration gap implies that a bank will lose (gain) } \\
\text { from an increase in interest rates. }\end{array}$ & + \\
\hline Credit risk & Ratio of risk-weighted assets to total assets. & + \\
\hline Risk aversion & $\begin{array}{l}\text { Ratio of capital in excess to the required minimum to risk-weighted } \\
\text { assets. }\end{array}$ & + \\
\hline Operational costs & Ratio of operational expenses to total assets. & + \\
\hline Size & Logarithm of total assets. & $+/-$ \\
\hline \multicolumn{3}{|l|}{ Other variables } \\
\hline $\mathrm{HH}$ index & $\begin{array}{l}\text { Herfindahl-Hirschman index (higher values imply a less competitive } \\
\text { environment) }\end{array}$ & + \\
\hline GDP growth & Real GDP growth rate. & + \\
\hline Inflation & Consumer price index. & + \\
\hline Short-term rate & 3-month swap rate. & + \\
\hline Yield curve slope & Difference between the 10 -year and the 3-month swap rates. & + \\
\hline
\end{tabular}

This table presents the dependent variables, and the bank-specific, the system-wide and the macroeconomic (control) variables. 


\section{DATA}

For the analysis, we use half-yearly individual bank level data from 1999H1 to 2008H1. Data are from banks' prudential reporting. The starting date of our sample is due to data limitations. We then chose to limit the time span of the analysis to the first half of 2008 to avoid entering in the rather exceptional and turbulent period of the GFC, when the "normal" relationships we are interested in have most likely been altered.

The number of banks included in the sample ranges from 651 in $2008 \mathrm{H} 1$ to 723 in $2002 \mathrm{H} 2$, as shown in Table 2 which reports also the composition in terms of parent/holding banks, subsidiaries, and banks not belonging to groups. The bank $X$ time observations add up to almost 13,000. The sample total assets range from 106 percent of GDP in 1999H1 to 157 percent in $2008 \mathrm{H} 1$ and account on average for 81 percent of the Italian banking system assets, with limited variations over time, from 74 percent in $2007 \mathrm{H} 1$ to 87 percent in $2002 \mathrm{H} 1$.

Table 2. Sample Composition: Number of Banks and Asset Size

\begin{tabular}{|c|c|c|c|c|c|c|c|c|c|c|c|c|c|c|c|c|c|c|c|}
\hline & $1999 \mathrm{H} 1$ & $1999 \mathrm{H} 2$ & $2000 \mathrm{H} 1$ & $2000 \mathrm{H} 2$ & $2001 \mathrm{H} 1$ & $2001 \mathrm{H} 2$ & $2002 \mathrm{H} 1$ & $2002 \mathrm{H} 2$ & $2003 \mathrm{H} 1$ & $\begin{array}{l}\text { Date } \\
2003 \mathrm{H} 2\end{array}$ & $2004 \mathrm{H} 1$ & $2004 \mathrm{H} 2$ & $2005 \mathrm{H} 1$ & $12005 \mathrm{H} 2$ & $2006 \mathrm{H} 1$ & $2006 \mathrm{H} 2$ & $2007 \mathrm{H} 1$ & $2007 \mathrm{H} 2$ & $2008 \mathrm{H} 1$ \\
\hline n. of banks & & & & & & & & & & & & & & & & & & & \\
\hline $\begin{array}{l}\text { total } \\
\text { of which: }\end{array}$ & 696 & 705 & 712 & 723 & 718 & 704 & 701 & 682 & 675 & 667 & 658 & 660 & 662 & 661 & 659 & 655 & 653 & 652 & 651 \\
\hline parent/consolidating banks & 64 & 59 & 59 & 60 & 60 & 59 & 59 & 63 & 65 & 65 & 65 & 65 & 67 & 68 & 68 & 67 & 66 & 62 & 62 \\
\hline subsidiaries & 93 & 104 & 119 & 122 & 124 & 120 & 125 & 117 & 114 & 115 & 113 & 117 & 117 & 115 & 115 & 113 & 113 & 114 & 120 \\
\hline individual banks & 539 & 542 & 534 & 541 & 534 & 525 & 517 & 502 & 496 & 487 & 480 & 478 & 478 & 478 & 476 & 475 & 474 & 476 & 469 \\
\hline $\begin{array}{l}\text { memo: } \\
\text { of which cooperative banks }\end{array}$ & 472 & 473 & 473 & 472 & 463 & 444 & 439 & 427 & 420 & 415 & 412 & 407 & 406 & 404 & 402 & 402 & 402 & 401 & 398 \\
\hline asset size (percentage) & & & & & & & & & & & & & & & & & & & \\
\hline $\begin{array}{l}\text { share ot total banking systen } \\
\text { share of GDP }\end{array}$ & $\begin{array}{l}77.4 \\
105.5\end{array}$ & $\begin{array}{c}79.6 \\
107.8\end{array}$ & $\begin{array}{c}81.0 \\
112.7\end{array}$ & $\begin{array}{l}81.1 \\
114.0\end{array}$ & $\begin{array}{l}80.3 \\
112.3\end{array}$ & $\begin{array}{c}86.5 \\
120.0\end{array}$ & $\begin{array}{l}87.0 \\
120.8\end{array}$ & $\begin{array}{l}82.8 \\
120.4\end{array}$ & $\begin{array}{c}83.0 \\
120.8\end{array}$ & $\begin{array}{l}83.7 \\
123.1\end{array}$ & $\begin{array}{c}82.0 \\
121.0\end{array}$ & $\begin{array}{c}82.5 \\
123.2\end{array}$ & $\begin{array}{l}81.3 \\
127.1\end{array}$ & $\begin{array}{c}81.6 \\
129.9\end{array}$ & $\begin{array}{c}81.5 \\
132.5\end{array}$ & $\begin{array}{l}80.0 \\
137.2\end{array}$ & $\begin{array}{l}73.7 \\
137.7\end{array}$ & $\begin{array}{l}80.3 \\
150.1\end{array}$ & $\begin{array}{c}80.2 \\
156.5\end{array}$ \\
\hline
\end{tabular}

Table 3 reports the summary statistics for the variables included in model and for the banks' total assets. The dynamics over time of the mean of each variable are presented in Table 4.

Table 3. Summary Statistics (percentage points unless otherwise stated)

\begin{tabular}{lcccc}
\hline & Obs & Mean & Std. Dev. & Median \\
\hline Bank variables & & & & \\
Total assets (1) & 12,894 & 2,591 & 12,689 & 236 \\
Net interest margin & 12,892 & 1.56 & 0.49 & 1.57 \\
Maturity trasformation & 12,833 & 59.10 & 23.68 & 58.31 \\
Interest rate risk & 12,894 & 4.79 & 7.09 & 3.43 \\
Credit risk & 12,894 & 67.51 & 18.30 & 66.91 \\
Risk aversion & 12,894 & 11.98 & 15.99 & 8.58 \\
Operational costs & 12,812 & 1.45 & 0.52 & 1.41 \\
System-wide variables & & & & \\
Herfindahl-Hirschman index & 19 & 2.20 & 0.42 & 2.11 \\
GDP growth & 19 & 0.65 & 0.73 & 0.64 \\
Inflation & 19 & 2.54 & 0.47 & 2.40 \\
Short-term rate & 19 & 3.30 & 0.94 & 3.24 \\
Yield curve slope & 19 & 1.32 & 0.70 & 1.45 \\
\hline This table presents the descriptive statistics of the bank-specific and the \\
system-wide variables. (1) Millions of euro.
\end{tabular}


Table 4. Sample Means by Date

(percentage points unless otherwise stated)

\begin{tabular}{|c|c|c|c|c|c|c|c|c|c|c|c|c|c|c|c|c|c|c|c|}
\hline & 1999 & 199 & 200 & 000 & 2001 & 2001 & $2002 \mathrm{r}$ & $2002 \mathrm{H}$ & 2003H1 & $\begin{array}{c}\text { Date } \\
2003 \mathrm{H} 2\end{array}$ & $2004 \mathrm{H}$ & $2004 \mathrm{H}$ & $2005 \mathrm{H} 1$ & 2005 & $006 \mathrm{H}$ & $2006 \mathrm{H}$ & $007 \mathrm{H}$ & $007 \mathrm{H}$ & $2008 \mathrm{H} 1$ \\
\hline \multicolumn{20}{|l|}{ Bank-specific variables } \\
\hline Total assets (1) & 1,741 & 1793.3 & 1,912 & 1,955 & 1,993 & 2,215 & 2,271 & 2,376 & 2,446 & 2,567 & 2,609 & 2,705 & 2,822 & 2,929 & 3,060 & 3,244 & 3,335 & 3,706 & 3,922 \\
\hline Net interest margin & 1.65 & 1.6537 & 1.71 & 1.83 & 1.77 & 1.65 & 1.59 & 1.56 & 1.54 & 1.47 & 1.49 & 1.44 & 1.43 & 1.43 & 1.46 & 1.49 & 1.45 & 1.48 & 1.44 \\
\hline Maturity trasformation & 39.58 & 44.788 & 47.10 & 48.28 & 48.83 & 48.44 & 50.30 & 53.59 & 55.58 & 57.75 & 59.94 & 62.80 & 64.84 & 67.19 & 70.00 & 74.89 & 76.38 & 79.47 & 80.86 \\
\hline Credit risk & 4.05 & 4.6811 & 4.56 & 5.19 & 4.19 & 4.76 & 4.34 & 4.65 & 4.83 & 5.11 & 4.17 & 4.30 & 4.11 & 4.35 & 4.27 & 4.80 & 5.28 & 6.25 & 7.21 \\
\hline Interest rate risk & 63.50 & 62.958 & 64.77 & 65.57 & 66.24 & 63.94 & 64.74 & 65.28 & 67.19 & 67.90 & 69.47 & 68.93 & 69.78 & 70.41 & 70.72 & 70.81 & 71.07 & 71.09 & 69.89 \\
\hline Risk aversion & 14.79 & 14.408 & 14.77 & 14.06 & 14.01 & 13.84 & 13.27 & 12.71 & 11.76 & 11.25 & 10.83 & 10.65 & 10.30 & 9.76 & 9.84 & 10.66 & 10.25 & 9.81 & 9.50 \\
\hline Operational costs & 1.61 & 1.5836 & 1.58 & 1.57 & 1.57 & 1.48 & 1.48 & 1.43 & 1.41 & 1.37 & 1.36 & 1.35 & 1.36 & 1.36 & 1.34 & 1.41 & 1.41 & 1.39 & 1.38 \\
\hline \multicolumn{20}{|l|}{ System-wide variables } \\
\hline Herfindahl-Hirschman index & 1.74 & 1.83 & 1.80 & 1.72 & 1.83 & 2.55 & 2.49 & 2.59 & 2.47 & 2.28 & 2.19 & 2.12 & 2.05 & 2.11 & 2.04 & 2.02 & 1.79 & 3.15 & 3.19 \\
\hline GDP growth & & & 2.12 & 1.74 & 0.41 & 0.01 & 0.64 & -0.02 & -0.45 & 0.93 & 0.90 & 0.17 & 0.91 & 0.69 & 1.20 & 1.76 & 0.22 & -0.17 & -0.12 \\
\hline Inflation & & & 2.70 & 2.70 & 2.90 & 2.20 & 2.20 & 2.90 & 2.90 & 2.50 & 2.40 & 2.40 & 2.10 & 2.10 & 2.40 & 2.10 & 1.90 & 2.80 & 4.00 \\
\hline Short-term rate & 2.86 & 3.06 & 3.91 & 4.88 & 4.67 & 3.87 & 3.40 & 3.24 & 2.53 & 2.14 & 2.07 & 2.14 & 2.13 & 2.24 & 2.75 & 3.41 & 3.94 & 4.61 & 4.67 \\
\hline Yield curve slope & 1.49 & 2.39 & 1.93 & 0.92 & 0.69 & 1.25 & 1.90 & 1.53 & 1.62 & 2.18 & 2.23 & 1.92 & 1.45 & 1.15 & 1.17 & 0.66 & 0.49 & 0.06 & -0.12 \\
\hline
\end{tabular}

\section{EMPIRICAL ESTIMATION}

The models given by equations (1) and (2) are estimated using the generalized method of moments (GMM) proposed by Blundell and Bond (1998), also known as system GMM estimator widely used in the literature to estimate a dynamic panel equation with small $\mathrm{T}$ and large $\mathrm{N}$ as in this paper. The framework accounts for endogeneity, controls for unobserved heterogeneity, and deals with the biases and inconsistencies typical of least square estimations, provided that the model is not subject to serial correlation of order two and the instruments used are valid.

We instrument for all the bank-specific regressors but bank size, which we consider to be pre-determined together with market concentration. We apply the instruments to the level equation and in order to limit their proliferation we cap to two the number of lags of the endogenous variables used as instruments. Macroeconomic variables are treated as exogenous.

To avoid that the estimates could be affected by the possible bank responses to the policy change that took place in 2006 we estimate equations (1) and (2) on the sub-period before the change, i.e., from June 1999 to December 2005.

Then, to study the implications of the increase in maturity transformation observed after the policy change we estimate equation (3) using a within-regression estimator with bank fixed effects and robust clustered standard errors. ${ }^{11}$ We think this approach is appropriate for our mostly descriptive analysis which does not feature a dynamic specification. The only exception is when equation (3) is estimated using the net interest margin as dependent variable: in this case we revert to the system GMM estimator used for equations (1) and (2). Equation (3) is estimated from five years before the policy change to the end of the sample,

\footnotetext{
${ }^{11}$ A fixed effect estimator is used as the Hausman test rejects the null hypothesis of random effects.
} 
i.e., from June 2001 to June 2008 . We use the time-window to select the constrained banks defined in Section III.B.

\section{RESUlts}

\section{A. Net Interest Margin, Maturity Transformation, and Interest Rates}

The results from the estimation of equations (1) and (2) are shown in Table 5. For all the specifications presented, the AR-test and the Hansen test confirm that the model is not subject to serial correlation and that the instruments used are valid. In particular, for the specifications (1)-(4) the AR-test rejects the hypothesis of serial correlation of order two, while for the specifications sub (5) and (6), the AR-test rejects the hypothesis of serial correlation of order 3 . This is a satisfactory result since in the specifications (4)-(6) the third and fourth lags of the endogenous variables are used as instruments for their current value. The baseline estimation sub (1) shows that maturity transformation, credit risk, and bank size are significantly associated with the net interest margin. The first two variables have the expected positive sign. The result for credit risk is in line with the existing literature, which generally finds a positive relationship between credit risk and the net interest margin. The result for contractual maturity transformation suggests that banks earn a higher spread when they perform higher maturity transformation, an intuitive but novel finding with no direct comparison in the empirical literature. The negative sign of bank size is against the ex-ante expectation but in line with Maudos and Fernández de Guevara (2004), and Fungáčová and Poghosyan (2011). It suggests that larger banks might give up part of their net interest margin to attract customer relationships beyond the lending business.

The non-significance of interest rate risk is in contrast with most of the literature. In principle, this may be due to interest rate risk being collinear with maturity transformation. So in order to test whether this is the case, in the specification sub (2) we re-estimate equation (1) without maturity transformation. Interest rate risk remains non-significant also sub (2) confirming that the non-significance sub (1) is not due to collinearity with maturity transformation. These results suggest instead that on average banks hedge their interest rate risk exposure, as confirmed by Hoffmann et al. (2017) for a sample of major euro area banks. The difference with most of the previous literature should not be too surprising. Interest rate risk exposure changes from banking system to banking system (mostly due to cross-country differences in the fixation of loan terms, and in particular mortgages, as shown by Hoffmann et al, 2017) and has also evolved over time with the advances in hedging practices. While in the past hedging the interest rate risk might not have been so common, over the last decades it has become a standard business practice by commercial banks, aiming at stabilizing the volatility of the net interest margin and hence at more closely linking the margin to the markup obtained on lending. We also find that under specification sub (1), differently from most of the available literature, operational costs, market concentration, and risk aversion are non-significant. 
The results for the estimation of the dynamic equation (2) are presented sub (3). The autoregressive component of the net interest margin is very significant in explaining the current level of the margin, both statistically and economically. The significance of the other variables is confirmed. In particular, after adjusting for the lagged dependent variable to obtain long-run coefficients, we find that the effect of maturity transformation remains unchanged relative to the estimation sub (1), while that of credit risk is about 60 percent higher (at 0.008 ), and that of size is about 30 percent lower (at 0.105 ). ${ }^{12}$

Somewhat different results are obtained in the specification sub (4) where we change the way we control for macroeconomic developments. Instead of using time dummies, we explicitly include macroeconomic variables. In particular, we add GDP growth, consumer price inflation, short-term interest rate, slope of the yield curve, and change terms for the latter two variables as in Alessandri and Nelson (2015). Differently however from Alessandri and Nelson (2015) whose focus is on the macroeconomic factors driving the net interest margin, the specification sub (4) is a blended approach which combines both bank-specific and macroeconomic controls.

Under this specification, for the bank-specific variables we confirm the significance of maturity transformation, interest rate risk and size and the non-significance of risk aversion, already shown sub (3). Different results are however obtained for operational costs and the Herfindal-Hirschman index. Operational costs are now significant with a positive sign, in line with most of the literature from Maudos and Fernández de Guevara (2004) onward. This confirms that the less efficient banks charge higher margins to compensate for their higher operational costs. The Herfindal-Hirschman index is also significant, but with a negative sign, suggesting that higher concentration is associated with lower net interest rate margins, a result in contrast with the ex-ante expectation and some of the literature. This finding could nonetheless be explained by the developments of the Italian banking system in the 2000s. During those years, banks grew bigger through a number of M\&As, thereby increasing concentration. However, this came as a response to a more open domestic market with a significant presence of, and competitive pressure from, foreign players. Thus, the increase in competitive pressure during this period could have exerted a downward pressure on income margins. ${ }^{13}$

\footnotetext{
${ }^{12}$ The adjustment is performed as $\beta /(1-\alpha(L))$ where $\beta$ is the coefficient to be adjusted, $\alpha$ is the coefficient of the lagged dependent variable and $\mathrm{L}$ is the lag operator. Setting $\mathrm{L}=1$ we get the comparable long-run effect of the variable of interest as $\beta /(1-\alpha)$.

${ }^{13}$ The reorganization of the Italian banking system, which began with the privatizations of the $1990 \mathrm{~s}$, has continued in the first decade of the 2000s: between 1998 and 2007 there have been 193 mergers among Italian banks and 133 acquisitions of Italian banks. During the period the largest Italian banks have also expanded abroad, with 52 acquisitions of foreign banks (Banca d'Italia, various years).
} 
Table 5. Net Interest Margin

\begin{tabular}{|c|c|c|c|c|c|}
\hline VARIABLES & $\begin{array}{c}\text { (1) } \\
\text { Baseline }\end{array}$ & $\begin{array}{c}\text { (2) } \\
\text { No Maturity } \\
\text { transformation }\end{array}$ & $\begin{array}{c}\text { (3) } \\
\text { Dynamic }\end{array}$ & $\begin{array}{l}\text { (4) } \\
\text { Macroecoomic } \\
\text { controls }\end{array}$ & $\begin{array}{c}(5) \\
\text { Maturity } \\
\text { transformation and } \\
\text { yield curve slope }\end{array}$ \\
\hline L.nim_ratio & & & $\begin{array}{c}0.507^{* * *} \\
(0.065)\end{array}$ & $\begin{array}{c}0.407^{\star * *} \\
(0.052)\end{array}$ & $\begin{array}{c}0.418^{* * *} \\
(0.055)\end{array}$ \\
\hline Maturity transformation & $\begin{array}{l}0.006^{* * *} \\
(0.002)\end{array}$ & & $\begin{array}{l}0.003^{* * *} \\
(0.001)\end{array}$ & $\begin{array}{l}0.002^{* *} \\
(0.001)\end{array}$ & $\begin{array}{l}0.000 \\
(0.001)\end{array}$ \\
\hline Interest rate risk & $\begin{array}{c}0.002 \\
(0.005)\end{array}$ & $\begin{array}{c}0.003 \\
(0.005)\end{array}$ & $\begin{array}{c}0.005 \\
(0.004)\end{array}$ & $\begin{array}{c}0.005 \\
(0.003)\end{array}$ & $\begin{array}{c}0.004 \\
(0.003)\end{array}$ \\
\hline Credit risk & $\begin{array}{l}0.005^{\star *} \\
(0.002)\end{array}$ & $\begin{array}{l}0.008^{* *} \\
(0.003)\end{array}$ & $\begin{array}{c}0.004^{* * *} \\
(0.001)\end{array}$ & $\begin{array}{c}0.004^{* * *} \\
(0.001)\end{array}$ & $\begin{array}{c}0.005^{\star * *} \\
(0.001)\end{array}$ \\
\hline Risk aversion & $\begin{array}{c}0.001 \\
(0.004)\end{array}$ & $\begin{array}{c}0.001 \\
(0.005)\end{array}$ & $\begin{array}{c}0.001 \\
(0.002)\end{array}$ & $\begin{array}{c}0.002 \\
(0.002)\end{array}$ & $\begin{array}{c}0.003 \\
(0.002)\end{array}$ \\
\hline Operational costs & $\begin{array}{l}-0.345 \\
(0.228)\end{array}$ & $\begin{array}{l}-0.382 \\
(0.235)\end{array}$ & $\begin{array}{c}0.171 \\
(0.130)\end{array}$ & $\begin{array}{l}0.364^{\star \star *} \\
(0.087)\end{array}$ & $\begin{array}{c}0.374^{* * *} \\
(0.082)\end{array}$ \\
\hline Size & $\begin{array}{c}-0.150^{\star \star *} \\
(0.020)\end{array}$ & $\begin{array}{c}-0.132^{* \star *} \\
(0.016)\end{array}$ & $\begin{array}{c}-0.052^{* \star \star} \\
(0.011)\end{array}$ & $\begin{array}{c}-0.048^{\star \star *} \\
(0.008)\end{array}$ & $\begin{array}{c}-0.042^{* \star *} \\
(0.008)\end{array}$ \\
\hline $\mathrm{HH}$ index & $\begin{array}{c}6.588 \\
(5.685)\end{array}$ & $\begin{array}{c}8.264 \\
(12.956)\end{array}$ & $\begin{array}{c}2.530 \\
(2.061)\end{array}$ & $\begin{array}{c}-0.086^{* * *} \\
(0.027)\end{array}$ & $\begin{array}{l}-0.029 \\
(0.023)\end{array}$ \\
\hline GDP growth & & & & $\begin{array}{l}-0.003 \\
(0.016)\end{array}$ & $\begin{array}{c}0.015 \\
(0.016)\end{array}$ \\
\hline Inflation & & & & $\begin{array}{c}0.000 \\
(0.015)\end{array}$ & $\begin{array}{c}0.020 \\
(0.014)\end{array}$ \\
\hline Short-term rate & & & & $\begin{array}{c}0.070^{* * *} \\
(0.015)\end{array}$ & $\begin{array}{c}0.054^{* * *} \\
(0.015)\end{array}$ \\
\hline Yield curve slope & & & & $\begin{array}{c}0.074^{* * *} \\
(0.020)\end{array}$ & $\begin{array}{l}-0.013 \\
(0.036)\end{array}$ \\
\hline D.Short-term rate & & & & $\begin{array}{c}-0.051^{* *} \\
(0.024)\end{array}$ & $\begin{array}{l}-0.031 \\
(0.026)\end{array}$ \\
\hline D.Yield curve slope & & & & $\begin{array}{c}-0.059^{* * *} \\
(0.019)\end{array}$ & $\begin{array}{l}-0.041^{* *} \\
(0.020)\end{array}$ \\
\hline Maturity transformation\#Yield curve slope & & & & & $\begin{array}{l}0.001^{\star *} \\
(0.000)\end{array}$ \\
\hline Constant & $\begin{array}{c}0.000 \\
(0.000)\end{array}$ & $\begin{array}{c}0.000 \\
(0.000)\end{array}$ & $\begin{array}{l}0.000 \\
(0.000)\end{array}$ & $\begin{array}{c}0.074 \\
(0.158)\end{array}$ & $\begin{array}{l}-0.002 \\
(0.152)\end{array}$ \\
\hline Observations & 8715 & 8732 & 8714 & 8023 & 8023 \\
\hline Time FE & yes & yes & yes & no & no \\
\hline Hansen test & 0.717 & 0.237 & 0.693 & 11.56 & 16.63 \\
\hline p-value & 0.949 & 0.888 & 0.983 & 0.316 & 0.164 \\
\hline Arellano Bond test for $\mathrm{AR}(1)$ & -0.704 & -0.208 & -0.989 & -4.450 & -4.348 \\
\hline p-value & 0.482 & 0.835 & 0.323 & 0.00 & 0.00 \\
\hline Arellano Bond test for $\mathrm{AR}(2)$ & 0.567 & 0.033 & 0.972 & 2.936 & 2.958 \\
\hline $\mathrm{p}$-value & 0.570 & 0.974 & 0.331 & 0.003 & 0.003 \\
\hline $\begin{array}{l}\text { Arellano Bond test for } \mathrm{AR}(3) \\
\mathrm{p} \text {-value }\end{array}$ & & & & $\begin{array}{c}-1.666 \\
0.096\end{array}$ & $\begin{array}{c}-1.619 \\
0.105\end{array}$ \\
\hline Number of instruments & 29 & 26 & 30 & 25 & 28 \\
\hline
\end{tabular}

As for the macroeconomic variables, contrary to the ex-ante expectation, GDP growth and consumer price inflation do not seem to matter for the bank net interest income, as they are not significant. The results for the interest rate variables indicate instead that the levels of both the short-term interest rates and the slope of the yield curve contribute positively to the banks' net interest margin, a finding in line with English et al. (2012) and Alessandri and Nelson (2015). As in Alessandri and Nelson (2015), we also find that the coefficients of the difference terms D.Short-term rate and D.Yield curve slope-that can be interpreted as short-term effects of interest rate changes-have a negative sign. The joint reading of the results for the interest rates variables suggests the presence of non-trivial frictions in the re-pricing of assets and liabilities such that, in the short run, unexpected increases in interest rates can result in a compression of banks' net interest margin. However, in the long run 
these frictions fade away and higher interest rates and a steeper yield curve slope contribute to higher net interest rate margins.

Given the interesting results for the slope of the yield curve, we explore the role of maturity transformation relative to the level of the yield curve, by including the interaction between these two variables, as shown sub (5). The results confirm the intuition that both maturity transformation and yield curve slope are not so relevant per se for bank profitability, but rather the net interest margin increases in the level of both maturity transformation and the slope of the yield curve, as shown by the positive and significant interaction between these two covariates.

The economic significance of the different variables is evaluated by comparing the changes in net interest margin that would be implied by a one standard deviation higher value of the explanatory variables. Looking at the dynamic specification with time dummies sub (3), the autoregressive component of the net interest margin has the highest weight, as it would increase the margin by 25 percent, followed by maturity transformation and credit risk, that would increase it by 7 percent. In the dynamic specification with macroeconomic controls sub (4), the economic significance of the variables already significant sub (3) is broadly stable. In addition, the economic significance of the autoregressive term of the net interest margin is of the same magnitude as that of operational costs, as they would increase the margin by 20 and 19 percent respectively. The economic significance of short-term interest rates and credit risk is the same, as they would both increase the net interest margin by 7 percent. Also maturity transformation and the slope of the yield curve have the same economic significance as they would both increase the net interest margin by 5 percent. Market concentration has the lowest economic significance at it would decrease the margin by 4 percent.

\section{B. Net Interest Margin, Balance Sheet, and Risk with a Regulation on Maturity Transformation}

The results for the interaction variable pol $x$ high is the one of interest to ascertain the implications on the selected dependent variable of the higher maturity transformation carried out by some banks after the regulatory change. We repeat each estimation for the two groups of constrained banks defined in Section III.B. The results for the two groups are labelled with (a) and (b) respectively, with (a) indicating the less conservative definition and (b) the stricter. ${ }^{14}$

\footnotetext{
${ }^{14}$ Based on the less strict definition 153 banks are identified as having increased maturity transformation beyond the pre-existing limit after the regulatory change (23.2 percent of the sample at the date when the policy change became effective). The stricter definition identifies instead 74 banks (11.1 percent of the sample).
} 
The first estimations of equation (3) aim to assess the changes in assets and liabilities composition, in terms of maturity, asset type, and interest rate.

The results in Table 6 show that those banks that after the policy change increased their maturity mismatch beyond the pre-existing limit did so by substantially reshuffling their assets (sub (1)) and their liabilities (sub (3)). In particular, the constrained banks increased their long-term assets (i.e., with remaining maturity longer than five years) relative to the rest of the sample, as indicated sub (1) by the positive sign of policy $x$ high and by the negative sign of policy. In this context the constrained banks also raised the share of mortgage lending in their portfolio, as shown by the significance of policy $x$ high sub (2) while no significant variation is observed for the rest of the sample. The changes on the liability side of the balance sheet contributed as well to the increase in the maturity transformation for the constrained banks, as their share of long-term liabilities increased less than the rest of the sample, as indicated sub (3) by the negative sign of policy $x$ high and by the positive sign of policy.

Table 6. Policy Change and Assets and Liabilities Composition

\begin{tabular}{|c|c|c|c|c|c|c|}
\hline \multirow[b]{2}{*}{ VARIABLES } & \multicolumn{2}{|c|}{$\begin{array}{c}1) \\
\text { Long-term assets }\end{array}$} & \multicolumn{2}{|c|}{$\begin{array}{c}(2) \\
\text { Mortgage lending }\end{array}$} & \multicolumn{2}{|c|}{$\begin{array}{c}(3) \\
\text { Long-term liabilities }\end{array}$} \\
\hline & (a) & (b) & (a) & (b) & (a) & (b) \\
\hline Policy & $\begin{array}{c}-0.056^{* *} \\
(0.026)\end{array}$ & $\begin{array}{c}-0.059^{* *} \\
(0.026)\end{array}$ & $\begin{array}{c}0.021 \\
(0.027)\end{array}$ & $\begin{array}{l}0.017 \\
(0.027)\end{array}$ & $\begin{array}{c}0.093^{* * *} \\
(0.022)\end{array}$ & $\begin{array}{c}0.094^{* * *} \\
(0.022)\end{array}$ \\
\hline Policy\#high & $\begin{array}{c}0.033^{* * *} \\
(0.004)\end{array}$ & $\begin{array}{l}0.028^{* * *} \\
(0.003)\end{array}$ & $\begin{array}{c}0.041^{* * *} \\
(0.005)\end{array}$ & $\begin{array}{l}0.035^{\star * * *} \\
(0.004)\end{array}$ & $\begin{array}{c}-0.009^{* * *} \\
(0.002)\end{array}$ & $\begin{array}{c}-0.005^{* * *} \\
(0.002)\end{array}$ \\
\hline Size & $\begin{array}{c}0.001 \\
(0.006)\end{array}$ & $\begin{array}{l}0.002 \\
(0.006)\end{array}$ & $\begin{array}{l}-0.001 \\
(0.010)\end{array}$ & $\begin{array}{l}-0.001 \\
(0.010)\end{array}$ & $\begin{array}{l}0.006^{* *} \\
(0.003)\end{array}$ & $\begin{array}{l}0.006^{\star *} \\
(0.003)\end{array}$ \\
\hline $\mathrm{HH}$ index & $\begin{array}{c}0.115^{\star * *} \\
(0.020)\end{array}$ & $\begin{array}{c}0.115^{\star \star *} \\
(0.020)\end{array}$ & $\begin{array}{c}0.072^{* * *} \\
(0.022)\end{array}$ & $\begin{array}{c}0.072^{\star * *} \\
(0.022)\end{array}$ & $\begin{array}{c}-0.067^{\star * *} \\
(0.016)\end{array}$ & $\begin{array}{c}-0.067^{\star \star *} \\
(0.016)\end{array}$ \\
\hline Constant & $\begin{array}{l}-0.143 \\
(0.107)\end{array}$ & $\begin{array}{l}-0.145 \\
(0.108)\end{array}$ & $\begin{array}{c}0.119 \\
(0.180)\end{array}$ & $\begin{array}{c}0.117 \\
(0.180)\end{array}$ & $\begin{array}{c}0.013 \\
(0.064)\end{array}$ & $\begin{array}{c}0.013 \\
(0.064)\end{array}$ \\
\hline Observations & 10058 & 10058 & 9921 & 9921 & 10058 & 10058 \\
\hline R-squared & 0.675 & 0.679 & 0.612 & 0.615 & 0.030 & 0.029 \\
\hline Bank FE & yes & yes & yes & yes & yes & yes \\
\hline Time FE & yes & yes & yes & yes & yes & yes \\
\hline
\end{tabular}

The estimation presented in Table 7 assesses the possible changes in the composition of longterm assets and liabilities by interest rate type, i.e., fixed vs. variable rate. In particular, it shows that the constrained banks had a relatively higher share of fixed rate long-term assets than the other banks after the policy change, as indicated sub (1) by the positive sign of the interaction term which partially offsets the negative sign of policy. No significant change is however observed on the liability side for the constrained banks. 
Table 8. Policy Change and Bank Risk Exposure

\begin{tabular}{|c|c|c|c|c|c|c|c|c|}
\hline \multirow[b]{2}{*}{ VARIABLES } & \multicolumn{2}{|c|}{$\begin{array}{c}(1) \\
\text { Credit risk - non-performing loans }\end{array}$} & \multicolumn{2}{|c|}{$\begin{array}{c}(2) \\
\text { Credit risk - average risk weight }\end{array}$} & \multicolumn{2}{|c|}{$\begin{array}{c}\text { (3) } \\
\text { Interest rate risk }\end{array}$} & \multicolumn{2}{|c|}{$\begin{array}{c}(4) \\
\text { Risk aversion }\end{array}$} \\
\hline & (a) & (b) & (a) & (b) & (a) & (b) & (a) & (b) \\
\hline Policy & $\begin{array}{l}-2.552^{* * *} \\
(0.628)\end{array}$ & $\begin{array}{l}-2.619^{* * *} \\
(0.718)\end{array}$ & $\begin{array}{l}34.217^{\star *} \\
(13.482)\end{array}$ & $\begin{array}{c}39.656^{* * *} \\
(14.507)\end{array}$ & $\begin{array}{c}-28.420^{* * *} \\
(5.966)\end{array}$ & $\begin{array}{c}-31.054^{* * *} \\
(6.412)\end{array}$ & $\begin{array}{l}-6.625 \\
(7.712)\end{array}$ & $\begin{array}{l}-6.039 \\
(8.373)\end{array}$ \\
\hline Policy\#high & $\begin{array}{l}-0.118 \\
(0.142)\end{array}$ & $\begin{array}{l}-0.048 \\
(0.132)\end{array}$ & $\begin{array}{l}-1.388 \\
(1.121)\end{array}$ & $\begin{array}{l}-0.731 \\
(0.862)\end{array}$ & $\begin{array}{l}3.011^{* * *} \\
(0.621)\end{array}$ & $\begin{array}{c}2.415^{\star * *} \\
(0.478)\end{array}$ & $\begin{array}{c}0.785 \\
(0.538)\end{array}$ & $\begin{array}{l}-0.641 \\
(0.757)\end{array}$ \\
\hline Size & $\begin{array}{l}-0.344 \\
(0.227)\end{array}$ & $\begin{array}{c}0.398 \\
(0.311)\end{array}$ & $\begin{array}{l}-2.485^{*} \\
(1.449)\end{array}$ & $\begin{array}{c}-2.891^{\star \star} \\
(1.256)\end{array}$ & $\begin{array}{l}-0.196 \\
(0.683)\end{array}$ & $\begin{array}{l}-0.633 \\
(0.819)\end{array}$ & $\begin{array}{c}-13.286^{* * *} \\
(2.386)\end{array}$ & $\begin{array}{c}-13.403^{\star * *} \\
(2.101)\end{array}$ \\
\hline $\mathrm{HH}$ index & $\begin{array}{l}1.801^{* * *} \\
(0.501)\end{array}$ & $\begin{array}{l}1.086^{*} \\
(0.563)\end{array}$ & $\begin{array}{l}-20.045^{\star *} \\
(10.152)\end{array}$ & $\begin{array}{l}-20.124^{\star *} \\
(10.221)\end{array}$ & $\begin{array}{c}23.062^{\star \star *} \\
(4.558)\end{array}$ & $\begin{array}{c}23.676^{\star * *} \\
(4.781)\end{array}$ & $\begin{array}{l}6.792 \\
(6.174)\end{array}$ & $\begin{array}{c}6.999 \\
(6.321)\end{array}$ \\
\hline Constant & $\begin{array}{l}6.075 \\
(4.096)\end{array}$ & $\begin{array}{l}-6.369 \\
(5.514)\end{array}$ & $\begin{array}{c}150.177^{* * *} \\
(33.513)\end{array}$ & $\begin{array}{c}153.297^{* * *} \\
(29.771)\end{array}$ & $\begin{array}{l}-34.326^{* *} \\
(13.528)\end{array}$ & $\begin{array}{l}-25.087^{\star} \\
(13.810)\end{array}$ & $\begin{array}{c}260.510^{* * *} \\
(38.202)\end{array}$ & $\begin{array}{c}260.510^{* * *} \\
(38.202)\end{array}$ \\
\hline Observations & 9768 & 12516 & 10058 & 12894 & 10058 & 12894 & 10058 & 12894 \\
\hline R-squared & 0.013 & 0.037 & 0.110 & 0.126 & 0.062 & 0.047 & 0.149 & 0.176 \\
\hline Bank FE & yes & yes & yes & yes & yes & yes & yes & yes \\
\hline Time FE & yes & yes & yes & yes & yes & yes & yes & yes \\
\hline
\end{tabular}

To answer the question whether the increase in maturity transformation carried out by the constrained banks after the policy change has had any implication on their net interest margin we re-estimate equation (2) augmented by the dummy variables policy and high and their interaction. Differently from the estimation of equation (2) here we include two lags of the dependent variable and use the third and fourth lags of the endogenous variables as instruments so that the differenced residuals do not exhibit significant AR(3) behavior. In addition, we estimate equation (2) over a different sample (i.e., from June 2001 to June 2008, instead of from June 1999 to December 2005) in order to be consistent with the rest of the estimates presented in this Section. The results are reported in Table 9 and are broadly consistent with the findings shown in Table $5 \mathrm{sub}$ (3). The lagged net interest margin is significant for both lags and so are maturity transformation and size. The only exception is credit risk which is non-significant in this estimation.

The results for the policy-related variables indicate that the policy change has been followed by a lower net interest margin for the constrained banks, as shown by the negative sign of the coefficient of the interaction variable both sub (a) and sub (b). This means that while on average a positive relationship between maturity transformation and net interest margin is confirmed by the coefficient of maturity transformation, an 'excessive' maturity mismatchproxied by a level beyond the pre-existing regulatory limit-did not lead to higher net interest margins but on the contrary had a negative effect on the net interest margin for the constrained banks. 
Table 9. Policy Change and Net Interest Margin

\begin{tabular}{|c|c|c|}
\hline \multirow[b]{2}{*}{ VARIABLES } & \multicolumn{2}{|c|}{ Net interest margin } \\
\hline & (a) & (b) \\
\hline L.nim_ratio & $\begin{array}{c}0.388^{\star * *} \\
(0.060)\end{array}$ & $\begin{array}{c}0.385^{\star * *} \\
(0.057)\end{array}$ \\
\hline L2.nim_ratio & $\begin{array}{c}0.372^{\star * *} \\
(0.038)\end{array}$ & $\begin{array}{c}0.377^{* * *} \\
(0.037)\end{array}$ \\
\hline Maturity transformation & $\begin{array}{l}0.002^{\star *} \\
(0.001)\end{array}$ & $\begin{array}{l}0.002^{* *} \\
(0.001)\end{array}$ \\
\hline Interest rate risk & $\begin{array}{c}0.001 \\
(0.002)\end{array}$ & $\begin{array}{c}0.001 \\
(0.002)\end{array}$ \\
\hline Credit risk & $\begin{array}{c}0.002 \\
(0.001)\end{array}$ & $\begin{array}{c}0.002 \\
(0.001)\end{array}$ \\
\hline Risk aversion & $\begin{array}{l}-0.001 \\
(0.002)\end{array}$ & $\begin{array}{l}-0.002 \\
(0.002)\end{array}$ \\
\hline Operational costs & $\begin{array}{c}0.094 \\
(0.073)\end{array}$ & $\begin{array}{c}0.091 \\
(0.073)\end{array}$ \\
\hline Size & $\begin{array}{c}-0.020^{* * *} \\
(0.006)\end{array}$ & $\begin{array}{c}-0.022^{* * *} \\
(0.007)\end{array}$ \\
\hline $\mathrm{HH}$ index & $\begin{array}{l}-0.394^{*} \\
(0.235)\end{array}$ & $\begin{array}{l}-0.376 \\
(0.238)\end{array}$ \\
\hline Policy & $\begin{array}{l}0.427^{*} \\
(0.249)\end{array}$ & $\begin{array}{c}0.404 \\
(0.252)\end{array}$ \\
\hline High & $\begin{array}{l}-0.014 \\
(0.019)\end{array}$ & $\begin{array}{c}0.005 \\
(0.023)\end{array}$ \\
\hline Policy\#high & $\begin{array}{c}-0.067^{\star \star \star} \\
(0.020)\end{array}$ & $\begin{array}{c}-0.069^{* \star *} \\
(0.027)\end{array}$ \\
\hline Constant & $\begin{array}{l}0.926^{*} \\
(0.516)\end{array}$ & $\begin{array}{c}0.928^{*} \\
(0.519)\end{array}$ \\
\hline Observations & 9729 & 9729 \\
\hline Time FE & yes & yes \\
\hline Hansen test & 14.12 & 16.12 \\
\hline p-value & 0.23 & 0.14 \\
\hline Arellano Bond test for $\mathrm{AR}(1)$ & -3.199 & -3.229 \\
\hline$p$-value & 0.00 & 0.00 \\
\hline Arellano Bond test for $\mathrm{AR}(2)$ & -2.039 & -2.129 \\
\hline $\mathrm{p}$-value & 0.04 & 0.03 \\
\hline Arellano Bond test for $\mathrm{AR}(3)$ & 0.639 & 0.666 \\
\hline $\mathrm{p}$-value & 0.52 & 0.51 \\
\hline Number of instruments & 36 & 36 \\
\hline \multicolumn{3}{|c|}{$\begin{array}{l}\text { This table presents the Blundell-Bond system GMM estimates of the } \\
\text { implications of the regulatory change for net interest margin. (a) and } \\
\text { (b) indicate two alternative definitions of the group of banks that (i) } \\
\text { were below the regulatory limit before the policy change and that (ii) } \\
\text { increased maturity transformation beyond the limit after the change. } \\
\text { Definition (a) is less conservative than (b) and hence includes more } \\
\text { banks. Hansen test, AR (1), AR (2), and AR(3) tests are provided at } \\
\text { the end of the table. Estimated robust standard errors are in } \\
\text { parentheses. }{ }^{* * *} p<0.01,{ }^{* *} p<0.05{ }^{*} p<0.1 \text {. }\end{array}$} \\
\hline
\end{tabular}

\section{Conclusions}

We have shown that higher maturity transformation is positively associated with banks' net interest margin, together with higher short-term rates and a steeper yield curve. Furthermore, maturity transformation is not only relevant per se, but it raises the net interest margin more the steeper is the yield curve. These intuitive results suggest that banks price the higher funding risk stemming from higher maturity transformation, though we cannot claim that by doing so they also fully account for the non-linearities and the tail risks to funding that can abruptly materialize during crisis episodes.

We have also shown that following a loosening of a regulatory limit on maturity transformation in Italy some banks increased their maturity transformation beyond the pre- 
existing limit. They did so by carrying out a significant rebalancing of their balance sheet, in terms of maturity, interest rate, and lending type, resulting in an increased exposure to interest rate risk and in a lower net interest margin than the rest of the sample.

While these results are rather novel, and as such should be interpreted with caution, they have important implications. In a low interest rate environment banks' net interest margin could benefit from a higher maturity transformation, particularly if it comes in conjunction with a steeper yield curve. Higher short-term rates are also likely to raise margins. However, two important caveats need to be highlighted. First, significant re-pricing frictions exist such that in the short-run an increase in interest rates and/or a steepening of the yield curve might not be as beneficial as expected for banks' net interest margin; second, excessive maturity transformation entails higher risk exposure without necessarily improving profitability.

While this study focuses only on the net interest margin, this is likely to be the income component most sensitive to interest rates and maturity transformation. To conclude, our findings suggest that (i) higher interest rates are likely to improve banks' profitability by increasing their net interest margin, but a smooth increase helps to give banks time to adjust their balance sheet and limit the risk of negative short-term effects, and (ii) higher maturity transformation is beneficial for banks' net interest margin but unregulated 'excessive' maturity transformation is undesirable both for net interest margin and risk exposure. The adoption of the NSFR, conceptually similar to the regulation that was in place in Italy, is therefore likely to constrain banks' incentives towards excessive maturity transformation thereby reducing their riskiness, without necessarily affecting their profitability. However, a proper calibration of this prudential tool is necessary, as highlighted also by Segura and Suarez (2017). 


\section{References}

Albertazzi, U., and L. Gambacorta, 2009, Bank profitability and the business cycle, Journal of Financial Stability, 5, 393-409.

Alessandri, P., and B.D. Nelson, 2015, Simple Banking: Profitability and the Yield Curve, Journal of Money, Credit and Banking, 47(1), 143-175.

Angbazo, L., 1997, Commercial bank net interest margins, default risk, interest-rate risk, and off-balance sheet banking, Journal of Banking \& Finance, 21(1), 55-87.

Banca d'Italia, Annual Report, various years.

Banca d'Italia, 2003, Bollettino di vigilanza, n. 12, dicembre.

Banca d'Italia, 2006, New Regulations for the Prudential Supervision of banks, Circular n. 263.

Banca d'Italia, 2013, Disposizioni di vigilanza per le banche, Circolare n. 285.

Banerjee, R.N., and Mio, H., 2014, The Impact of Liquidity Regulation on Banks, BIS Working Papers, n. 470.

Basel Committee on Banking Supervision, 2004, Principles for the management and supervision of interest rate risk, Bank for International Settlements.

Basel Committee on Banking Supervision, 2006, International convergence of capital measurement and capital standards: a revised framework, Bank for International Settlements.

Basel Committee for Banking Supervision, 2010, Basel III: International framework for liquidity risk, Bank for International Settlements.

Basel Committee for Banking Supervision, 2011, Basel III: A global regulatory framework for more resilient banks and banking systems - revised version June 2011, Bank for International Settlements. 
Beck, T., and H. Hesse, 2009, Why are interest spreads so high in Uganda?, Journal of Development Economics, 88(2), 192-204.

Berger, A.N., S.D. Bonime, D. Covitz, and D. Hancock, 2000, Why Are Bank Profits So Persistent? The Roles of Product Market Competition, Informational Opacity, and Regional/Macroeconomic Shocks, Journal of Banking \& Finance, 24, 1203-1235.

Blundell, R., and S. Bond, 1998, Initial conditions and moment restrictions in dynamic panel data models, Journal of Econometrics, 87, 115-143.

Bologna, P., 2015, Structural Funding and Bank Failures, Journal of Financial Services Research, 47(1), 81-113.

Bonner, C., 2012, Liquidity Regulation, Funding Costs and Corporate Lending, DNB Working Papers, n. 361.

Bonner, C., and S. Eijffinger, 2012, The Impact of the LCR on the Interbank Money Market, CEPR Discussion Paper, n. 9142.

Brock, P.L., and L. Rojas Suarez, 2000, Understanding the behavior of bank spreads in Latin America, Journal of Development Economics, 63(1), 113-134.

Brunnermeier, M.K., and M. Oehmke, 2013, The Maturity Rat Race, The Journal of Finance, $68(2), 483-521$.

Claeys, S., and R. Vander Vennet, 2008, Determinant s of bank interest margins in Central and Eastern Europe: a comparison with the West, Economic Systems, 32, 197-216.

Claessens, S. and L. Laeven, 2004, What Drives Bank Competition? Some International Evidence, Journal of Money, Credit and Banking, 36(3), 563-583.

de Haan, L., and J.W. van den End, 2013, Bank liquidity, the maturity ladder, and regulation, Journal of Banking \& Finance, 37, 3930-3950. 
Demirgüç-Kunt, A., L. Laeven, and R. Levine, 2004, Regulations, Market Structure, Institutions, and the Cost of Financial Intermediation, Journal of Money, Credit and Banking, 36(3): 593-622.

DeYoung R., and D.E. Nolle, 1996, Foreign-Owned Banks in the United States: Earning Market Share or Buying It?, Journal of Money, Credit and Banking, 28(4), 622-636.

Duijm , P. and P. Wierts, 2016, The effects of liquidity regulation on bank assets and liabilities, International Journal of Central Banking, 12(2), 385-411.

English, W.P., S.J. Van den Heuvel, and E. Zakrajsek, 2012, Interest Rate Risk and Bank Equity Valuations, Finance and Economics Discussion Series, Divisions of Research \& Statistics and Monetary Affairs Federal Reserve Board, Washington, D.C., n. 2012-26.

Entrop, O., C. Memmel, B. Ruprecht, and M. Wilkens, 2015, Determinants of bank interest margins: Impact of maturity transformation, Journal of Banking \& Finance, 5, 1-19.

Esposito, L., A. Nobili, and T. Ropele, 2015, The Management of Interest Rate Risk During the Crisis: Evidence from Italian Banks, Journal of Banking \& Finance, 59(C), 486-504.

European Central Bank, 2014, Financial Stability Review, November.

European Systemic Risk Board, 2014a, Flagship report on macro-prudential policy in the banking sector.

European Systemic Risk Board, 2014b, The ESRB Handbook on Operationalising Macroprudential Policy in the Banking Sector.

Fungáčová, Z., and T. Poghosyan, 2011, Determinants of Bank Interest Margins in Russia: Does Bank Ownership Matter?, Economic Systems, 35(4), 481-495

Goldstein, M., and P. Turner, 2004, Controlling Currency Mismatches in Emerging Markets, Washington: Institute for International Economics.

Hawtrey, K., and H. Liang, 2008, Bank interest margins in OECD countries, The North American Journal of Economics and Finance, 19(3), 249-260. 
Hellwig, M., 2008, Systemic Risk in the Financial Sector: An Analysis of the SubprimeMortgage Financial Crisis, Preprints of the Max Planck Institute for Research on Collective Goods, Bonn 2008/43.

Hicks, J., 1946, Value and Capital: An Inquiry Into Some Fundamental Principles of Economic Theory, Oxford: Clarendon Press.

Ho, T.S., and A. Saunders, 1981, The determinants of bank interest margins: theory and empirical evidence, Journal of Financial and Quantitative Analysis, 16(4), 581-600.

Hoffmann, P., S. Langfield, F. Pierobon, G. Vuillemey, 2017, Who bears interest rate risk?, available at SSRN: https://ssrn.com/abstract=3062435, revise and resubmit: Review of Financial Studies.

International Monetary Fund, 2013, Global Financial Stability Report, October.

International Monetary Fund, 2014, Staff Guidance on Macroprudential Policy.

Laeven, L., and G. Majnoni, 2005, Does judicial efficiency lower the cost of credit?, Journal of Banking \& Finance, 29(7), 1791-1812.

Maudos, J., and J. Fernández de Guevara, 2004, Factors explaining the interest margin in the banking sector of the European Union, Journal of Banking \& Finance, 28(9), 2259-2281.

Maudos, J., and L. Solís, 2009, The determinants of bank net interest margin in the Mexican banking system: an integrated model, Journal of Banking \& Finance, 33(10), 1920-1931.

Purnanandam, A., 2007, Interest rate derivatives at commercial banks: An empirical investigation, Journal of Monetary Economics, 54, 1769-1808.

Saunders, A., and L. Schumacher, 2000, The determinants of bank interest rate margins: an international study, Journal of International Money and Finance, 19(6), 813-832.

Segura, A. and J. Suarez, 2017, How Excessive Is Banks' Maturity Transformation?, Review of Financial Studies, 30(10), 3502-3537, https://doi.org/10.1093/rfs/hhx054. 
van Rixtel, A., and G. Gasperini, 2013, Financial crises and bank funding: recent experience in the euro area, BIS Working Paper, n. 406.

Vasquez, F., and P. Federico, 2012, Bank Funding Structures and Risk: Evidence from the Global Financial Crisis, IMF Working Paper, n. WP/12/29.

Williams, B., 2007, Factors determining net interest margins in Australia: domestic and foreign banks, Financial Markets, Institutions and Instruments, 16, 145-165. 


\section{Appendix I. The Italian Regulatory Limit on Bank Maturity Transformation}

The institutional reforms of the banking system that took place in Italy at the beginning of the 1990s cleared the way to the universal banking model by abolishing the institutional separation between financial intermediaries providing long-term financing and those focused on short- and medium-term lending. A regulation to limit bank maturity transformation was introduced by the Italian authorities in 1993 (Limite alla trasformazione delle scadenze) with the aim to prevent banks from excessively growing their long-term exposures without a proportional lengthening of the maturity of their liabilities, limiting therefore the possibility to incur in excessive maturity transformation and structural funding risk exposure. ${ }^{1}$ The regulation consisted of the following three rules:

$$
\begin{aligned}
& \text { 1. real_estate }+ \text { associates }<=\text { regulatory _capital } \\
& \text { 2. long_term_assets }<\text { sur } 1+\text { non_maturing_liab+long_term_liab+0.4medium_term_liab+ } \\
& +0.1 \text { short_term_customer_liab } \\
& \text { 3. medium_term_assets }<\text { sur2 }+0.6 \text { medium_term_liab+ } \\
& +0.2 \text { (short_term_customer_liab+bank_liab) }
\end{aligned}
$$

Where sur $1=$ regualtory_capital - real_estate-associates

and

$$
\begin{aligned}
& \text { sur2 }=\text { sur1+non_maturing_liab+long_term_liab+0.4medium_term_liab+ } \\
& +0.1 \text { short_term_customer_liab-long_term_assets }
\end{aligned}
$$

and with long-term assets and liabilities being those with maturities longer than 5 years, medium-term assets and liabilities being those with maturities between 1.5 and 5 years, short-term customer liabilities being those with maturities up to 1.5 year, and interbank liabilities being those with being those with maturities between 3 months and 1.5 year (Banca d'Italia, 2003).

The regulation was then simplified by reducing the number of rules to two in December 2003 (Banca d'Italia, 2003). In the revised framework, the first of the three rules was left unchanged while the second new rule resulted from the combination of the pre-existing second and third rules. As part of the revision a recalibration of the weightings attached to the various assets and liabilities took place. The change of weightings aimed at better reflecting the differences of assets and liabilities maturities, without however any significant implication on the policy stance.

\footnotetext{
${ }^{1}$ The rationale for this regulation was that the banks that before the institutional reform were engaged in shorter term lending only could not have been adequately prepared to manage the changes in their risk profile that would have followed from an increase in long-term lending after the reform.
} 
After the 2003 revision, the rules that banks had to comply with were the following:

$$
\begin{aligned}
& \text { 1. real_estate }+ \text { associates }<=\text { regulatory_capital } \\
& \text { long_term_assets }+0.5 \text { medium_term_assets }<\text { sur }+ \text { non_maturiting _liab }+ \\
& \text { 2. }+ \text { long_term_liab }+0.5 \text { medium_term_liab }+ \\
& +0.25(\text { short_term_customer_liab+bank_liab) }
\end{aligned}
$$

\begin{abstract}
All the maturities referred to the residual contractual maturity, which is the relevant time dimension of maturity mismatch to measure the effective maturity transformation. The time to contractual maturity is therefore different from the time to re-pricing, relevant to capture interest rate risk.
\end{abstract}

The regulation was applied at consolidated level only, in order to make it neutral with respect to banks' organizational choices.

The regulation, unique in its nature in the context of the European single market, was then abolished in 2006, leaving in place only the first rule which is no more formally referred to as a limit to maturity transformation (Banca d'Italia, 2013) and that is so loose to be extremely unlikely to become a binding constrain for banks in normal operating conditions. ${ }^{2}$

\footnotetext{
${ }^{2}$ Banca d'Italia, Istruzioni di Vigilanza per le banche, Circolare n. 229, April 21, 1999, 11 th update March 28, 2006 and delibera CICR February 22, 2006, then published on the Gazzetta Ufficiale n. 86, April 12, 2006.
} 